\title{
Effect of dexmedetomidine and propofol sedation on the prognosis of children with severe respiratory failure: a systematic review and meta-analysis
}

\author{
Zizhen Xiao", Tao He ${ }^{1}$, Xinping Jiang ${ }^{2}$, Fengyong Xie ${ }^{1}$, Lihua Xia ${ }^{1}$, Huiming Zhou ${ }^{2}$ \\ ${ }^{1}$ Department of Anesthesiology, The Central Hospital of Loudi, Loudi, China; ${ }^{2}$ Department of Pediatrics, The Central Hospital of Loudi, Loudi, \\ China \\ Contributions: (I) Conception and design: Z Xiao, T He; (II) Administrative support: H Zhou; (III) Provision of study materials or patients: F Xie; (IV) \\ Collection and assembly of data: L Xia; (V) Data analysis and interpretation: Z Xiao, T He; (VI) Manuscript writing: All authors; (VII) Final approval \\ of manuscript: All authors. \\ Correspondence to: Huiming Zhou. Department of Pediatrics, The Central Hospital of Loudi, Louxing District, Loudi 417000 , China. \\ Email: 13407389865@163.com.
}

Background: During treatment of acute respiratory failure (ARF) in children, sedation can reduce pain, improve tolerance, and reduce the incidence of adverse events, so selecting an appropriate sedation strategy is very important for improving prognosis and quality of life. Both dexmedetomidine and propofol have good sedative effects, so we investigated the application of these drugs in critically ill children with ARF by literature search and meta-analysis.

Methods: We searched Embase, The Cochrane Library, PubMed, Ovid, Clinicaltrials.org, and Google Scholar for randomized controlled trials (RCTs) preferentially but not exclusively, and used RevMan 5.4 to analyze the screened literature.

Results: Seven studies were included in the quantitative meta-analysis, with a total of 1,188 patients. There was no significant difference in the effect of dexmedetomidine and propofol on the duration of tracheal intubation in children with ARF [mean difference (MD) $=-0.05 ; 95 \%$ confidence interval (CI): $(-0.42$, $0.32) ; Z=0.26 ; P=0.79$, but dexmedetomidine sedation could reduce the intensive care unit (ICU) stay in children with ARF $[\mathrm{MD}=-0.62 ; 95 \% \mathrm{CI}:(-1.08,-0.16) ; \mathrm{Z}=2.65 ; \mathrm{P}=0.008]$, and shorten the total hospital stay $[\mathrm{MD}=-1.94 ; 95 \% \mathrm{CI}:(-2.63,-1.25) ; \mathrm{Z}=5.48 ; \mathrm{P}<0.00001]$. There was no significant effect on mortality between the two groups [odds ratio $(\mathrm{OR})=0.48 ; 95 \% \mathrm{CI}:(0.19,1.25) ; \mathrm{Z}=1.50 ; \mathrm{P}=0.13$ ]. The incidence rate of bradycardia with dexmedetomidine sedation was higher than with propofol [OR $=12.30 ; 95 \%$ CI: $(2.28$, 66.47); $\mathrm{Z}=2.92 ; \mathrm{P}=0.004]$, and the incidence of hypotension was also higher $[\mathrm{OR}=6.99,95 \% \mathrm{CI}:(1.22$, 39.86); $\mathrm{Z}=2.19 ; \mathrm{P}=0.03]$.

Discussion: Compared with propofol, dexmedetomidine can significantly reduce the ICU stay and hospital stay. However, bradycardia and hypotension may occur during the use of dexmedetomidine, which requires close attention and timely intervention.

Keywords: Dexmedetomidine; propofol; pediatric respiratory failure

Submitted Dec 27, 2021. Accepted for publication Feb 16, 2022.

doi: $10.21037 / \mathrm{tp}-22-20$

View this article at: https://dx.doi.org/10.21037/tp-22-20 


\section{Introduction}

Respiratory failure in children is defined as dyspnea due to various causes of respiratory physiological dysfunction, and acute respiratory failure (ARF) is common $(1,2)$. Pediatric respiratory failure is a clinically critical illness that can cause death in children in the pediatric intensive care unit (PICU). In addition to effective control of the primary disease (pulmonary infection, cerebral edema), oxygen therapy should be given to patients with respiratory insufficiency, and tracheal intubation and mechanical ventilation (MV) should be given when necessary (3). During treatment, sedative therapy can reduce the pain and subjective discomfort caused by $M V$, improve the tolerance of the pediatric patient, reduce the incidence of accidental removal of ventilation catheters, ultimately reduce cardiovascular and respiratory instability, shorten the PICU admission time and total hospital stay, and reduce mortality $(4,5)$. However, prolonged sedation may also lead to adverse effects such as memory and cognitive impairment, respiratory depression, and changes in cardiovascular dynamics; therefore, the selection of an appropriate sedation strategy is important for improving the prognosis and quality of life (6). Dexmedetomidine, a highly potent and selective pharmacological $\alpha 2$-adrenergic receptor agonist, is widely used for clinical surgical anesthesia and intensive care unit (ICU) sedation because of its good analgesic, sedative, and anti-sympathetic effects (7). However, there is still a lack of evidence on whether its use is superior to other commonly used sedative drugs (e.g., midazolam and propofol) in the treatment of MV children with respiratory failure. Kim et al. (8) compared the outcomes between dexmedetomidine as a tranquilizer and propofol in the course of pediatric MRI, but there is no clinical comparison in children with respiratory failure yet. A recent meta-analysis by Dong (9) compared dexmedetomidine with other sedative drugs in MV, but the included patients were all adults, not children. In this study we summarized the relevant studies to on the application of dexmedetomidine for sedative effect in the treatment of ARF in children. We present the following article in accordance with the PRISMA reporting checklist (available at https://tp.amegroups.com/article/ view/10.21037/tp-22-20/rc).

\section{Methods}

\section{Database and search strategy}

We searched Embase, The Cochrane Library, PubMed, Ovid, and additionally searched the clinical experimental research in Clinicaltrials.org. We also used the search function of Google Scholar to search for other possibly relevant literature. We set the search time from database construction to November 2021 and used the keyword combination of (dexmedetomidine OR DEX) AND (propofol) OR (sedation) OR (respiratory failure OR acute respiratory failure OR ARF) OR (Mechanical ventilation OR MV).

\section{Literature inclusion criteria}

(I) Study type: English language only, and randomized controlled trials (RCTs) preferred. (II) Study subjects: all patients were admitted to a PICU, aged $<18$ years, with respiratory failure caused by primary disease (pneumonia infection, cerebral edema, pulmonary edema), with hypoxemia or hypercapnia as the main symptom. (III) Intervention measures: all children were given $\mathrm{MV}$ and either dexmedetomidine or propofol to expected depth of sedation (i.e., two cohorts or groups). (IV) At least one expected outcome indicator: length of hospital stay, mortality, PICU stay, duration of MV, adverse reaction rate, and complete data are available.

\section{Literature exclusion criteria}

(I) Subjects were mainly adults; (II) investigations, case analysis and review of non-RCT; (III) incomplete or no data.

\section{Literature screening}

After literature retrieval, all studies were imported into Endnote X9 software for exclusion of duplicate literature. Next, two researchers read the title and abstract for further screening. If the original text was not available, the correspondence author was contacted by email and telephone to obtain the full text.

\section{Literature quality evaluation and risk of bias assessment}

The analysis tool RevMan 5.4 provided by the Cochrane Collaboration was used to assess the risk of bias of the included articles. We used Jadad scale to evaluate the quality of the study, and a score of more than 3 was regarded as a high-quality study.

\section{Outcome indicators}

We only counted and analyzed the six most common 


\section{Identification of studies via databases}
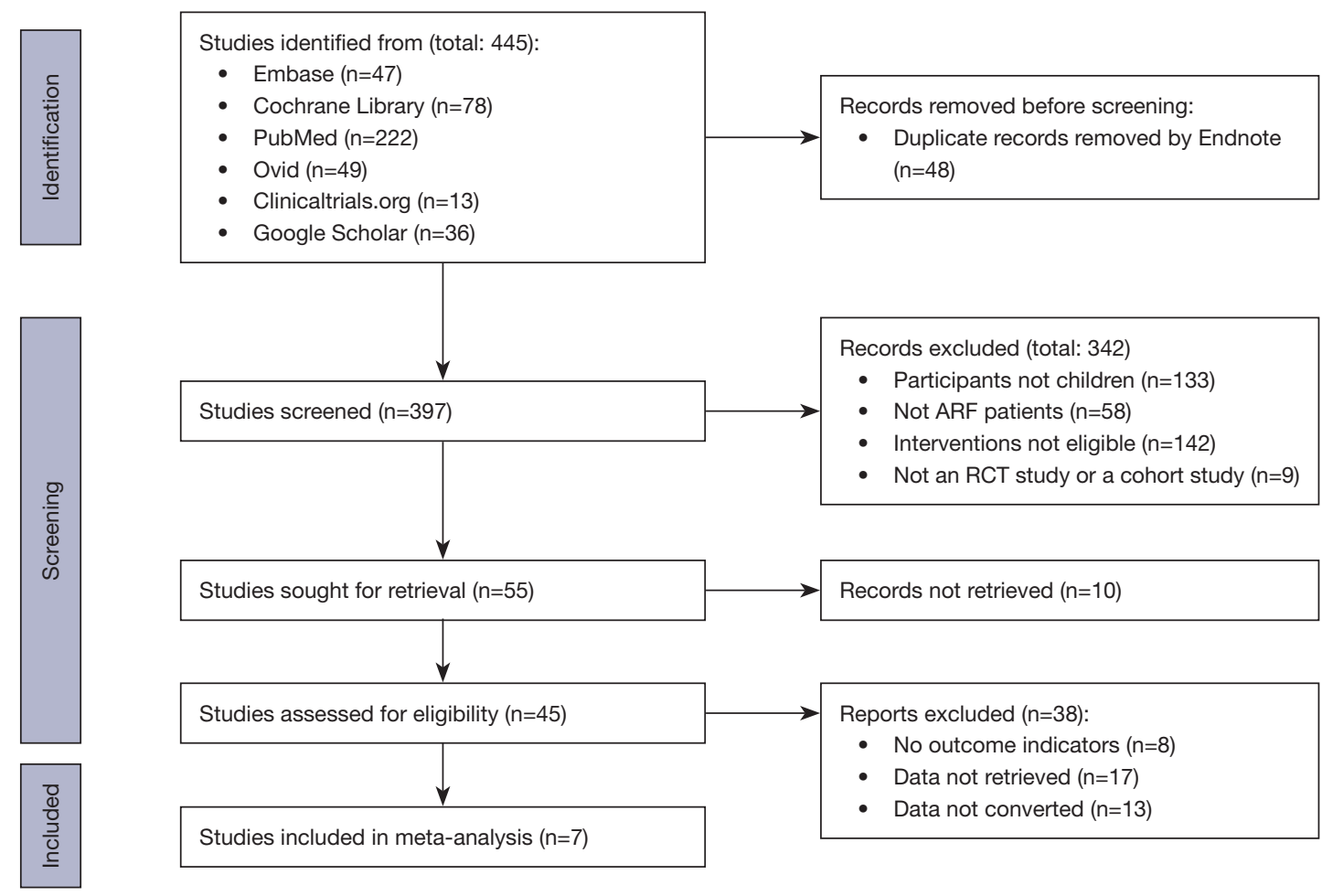

Figure 1 Literature selection flow chart. ARF, acute respiratory failure.

outcome indicators: (I) duration of endotracheal intubation; (II) ICU length of stay; (III) length of hospital stay; (IV) mortality; (V) incidence of adverse reactions (bradycardia); (VI) incidence of adverse reactions (hypotension).

\section{Data extraction}

Two researchers independently extracted the relevant data: author, publication year and month, grouping method, number of cases in each group, age of children, sex ratio, weight, primary disease diagnosis, complications, intervention methods and sedative dose. After data extraction, the results of each researcher were cross-checked and any differences generated were discussed and finally determined.

\section{Statistical methods}

(I) Meta-analysis software was RevMan 5.4. (II) Continuous variables were statistically analyzed by inverse variance, effect size is reported using mean difference (MD) and
95\% confidence interval (CI), and effect size is reported as odds ratio (OR) and 95\% CI for binary variables; $\mathrm{P}<0.05$ indicated the results were statistically significant. (III) Forest plot descriptive statistics were used for comparisons. (IV) Literature heterogeneity was analyzed by $\mathrm{I}^{2}$ analysis and $\mathrm{Q}$ test; heterogeneity of results was indicated by $\mathrm{I}^{2}>50 \%$ or $\mathrm{P}<0.1$; the $\mathrm{OR}$ value was obtained using a random-effects or fixed-effects model as applicable. (V) If the heterogeneity analysis suggested heterogeneity between studies, a heterogeneity source survey was performed using a case-by-case exclusion method, and general description analysis was adopted when the heterogeneity source could not be judged. (VI) Sensitivity analysis was performed by comparing the random-effect and fixed-effect results. (VII) Funnel plot was used to indicate publication bias.

\section{Results}

\section{Literature screening}

The flow chart of literature selection is shown in Figure 1: 7 
Table 1 Basic characteristics, intervention measures and outcome indicators of included literature

\begin{tabular}{|c|c|c|c|c|c|c|c|c|c|}
\hline Author & $\begin{array}{l}\text { Publication } \\
\text { year }\end{array}$ & Type & $\begin{array}{l}\text { Primary } \\
\text { disease }\end{array}$ & $\begin{array}{c}\text { Age } \\
\text { (years) }\end{array}$ & $E / C(n)$ & Experiment group & Control group & Outcome & $\begin{array}{l}\text { Jadad } \\
\text { Score }\end{array}$ \\
\hline $\begin{array}{l}\text { Erickson } \\
\text { et al. (10) }\end{array}$ & 2020 & RCT & $\begin{array}{l}\text { MV children } \\
\text { with ARF }\end{array}$ & $1-13$ & $29 / 28$ & $\begin{array}{l}\text { Dexmedetomidine } \\
1.0 \mu \mathrm{g} / \mathrm{kg} / \mathrm{h}\end{array}$ & $\begin{array}{l}\text { Propofol (maximum } \\
\text { dose } 4 \mathrm{mg} / \mathrm{kg} / \mathrm{h} \text { ) }\end{array}$ & $\begin{array}{l}1 \text { (2) } 3 \\
\text { (4) } 5 \text { (6) }\end{array}$ & 3 \\
\hline $\begin{array}{l}\text { Curley } \\
\text { et al. (11) }\end{array}$ & 2015 & $\begin{array}{l}\text { Cluster- } \\
\text { randomized trial }\end{array}$ & $\begin{array}{l}\text { Children with } \\
\text { ARF }\end{array}$ & $2-18$ & $287 / 171$ & $\begin{array}{l}\text { Dexmedetomidine } \\
1.0 \mu \mathrm{g} / \mathrm{kg} / \mathrm{h}\end{array}$ & $\begin{array}{l}\text { Propofol with lowest } \\
\text { effective dose }\end{array}$ & $\begin{array}{l}1 \text { (2) } \\
\text { (3) } 4 \text { ) }\end{array}$ & 3 \\
\hline $\begin{array}{l}\text { Tosun } \\
\text { et al. (13) }\end{array}$ & 2006 & RCT & $\begin{array}{l}\text { Children with } \\
\text { ARF }\end{array}$ & $1-16$ & $22 / 22$ & $\begin{array}{l}0.7 \mathrm{~g} / \mathrm{kg} / \mathrm{h} \text { of } \\
\text { dexmedetomidine } \\
\text { and } 1 \mathrm{mg} / \mathrm{kg} / \mathrm{h} \text { of } \\
\text { ketamine }\end{array}$ & $\begin{array}{l}100 \mu \mathrm{g} / \mathrm{kg} / \mathrm{min} \text { of } \\
\mathrm{propofol} \text { and } \\
1 \mathrm{mg} / \mathrm{kg} / \mathrm{h} \text { of } \\
\text { ketamine }\end{array}$ & (5) 6 & 3 \\
\hline $\begin{array}{l}\text { Ruokonen } \\
\text { et al. (15) }\end{array}$ & 2009 & RCT & $\begin{array}{l}\text { Children with } \\
\text { ARF }\end{array}$ & $1-17$ & $41 / 44$ & $\begin{array}{l}\text { Dexmedetomidine } \\
0.3-1.4 \mu \mathrm{g} / \mathrm{kg} / \mathrm{h}\end{array}$ & $\begin{array}{l}\text { Propofol } \\
0.5-3 \mathrm{mg} / \mathrm{kg} / \mathrm{h}\end{array}$ & (2) 5 (6) & 4 \\
\hline $\begin{array}{l}\text { Jakob } \\
\text { et al. (16) }\end{array}$ & 2012 & $\mathrm{RCT}$ & $\begin{array}{c}\text { Children with } \\
\text { ARF }\end{array}$ & $1-18$ & $223 / 214$ & $\begin{array}{l}\text { Dexmedetomidine } \\
0.2-1.4 \mu \mathrm{g} / \mathrm{kg} / \mathrm{h}\end{array}$ & $\begin{array}{l}\text { Propofol } \\
0.3-4.0 \mathrm{mg} / \mathrm{kg} / \mathrm{h}\end{array}$ & (1) (2) & 4 \\
\hline
\end{tabular}

Outcomes: (1) duration of endotracheal intubation; (2) ICU length of stay; (3) length of hospital stay; (4) mortality; (5) bradycardia; (6) hypotension. E/C, experiment/control; RCT, randomized controlled trial; MV, mechanical ventilation; ARF, acute respiratory failure; CABG, coronary artery bypass graft; ICU, intensive care unit.

studies with a total of 1,188 patients were finally included in the quantitative meta-analysis (10-16). Basic characteristics, intervention measures and outcome indicators of all studies are shown in Table 1.

\section{Literature quality and bias evaluation}

All studies (10-16) were RCTs in the type of random grouping and all described the generation method of random sequence. However, the allocation concealment method was not described in all the literature $(12,14)$, the others used sealed opaque envelopes to conceal the numbers. The studies (10-13) clearly indicated that the blind method was not implemented, which might introduce bias to the final results. All studies recorded the dropout cases in detail, without significant selective reporting bias and other biases, as shown in Figures 2,3.

\section{Meta-analysis}

\section{Tracheal intubation time (days)}

A total of 4 studies $(10,11,14,16)$ reported the tracheal intubation time after the intervention of the two sedatives, with statistical heterogeneity in the literature $\left(\mathrm{I}^{2}=59 \%\right.$; $\mathrm{P}=0.06)$. Random-effects model was used. Metaanalysis showed no significant difference in the effect of dexmedetomidine and propofol on the tracheal intubation time in children with ARF $[M D=-0.05 ; 95 \%$ CI: $(-0.42$, 0.32); $\mathrm{Z}=0.26 ; \mathrm{P}=0.79]$, as shown in Figure 4.

\section{ICU length of stay (days)}

A total of 6 studies (10-12,14-16) reported ICU admission time after the intervention of the two sedatives. There was statistical heterogeneity between them $\left(\mathrm{I}^{2}=61 \% ; \mathrm{P}=0.03\right)$. Random-effects model was used. Meta-analysis showed that dexmedetomidine reduced ICU admission time in children with ARF compared with propofol $[\mathrm{MD}=-0.62 ; 95 \% \mathrm{CI}$ : $(-1.08,-0.16) ; \mathrm{Z}=2.65 ; \mathrm{P}=0.008]$, as shown in Figure 5 .

\section{Length of hospital stay (days)}

A total of 3 studies (10-12) reported the total hospital stay after the intervention of the two sedatives. There was no statistical heterogeneity $\left(\mathrm{I}^{2}=0 \% ; \mathrm{P}=0.81\right)$. The fixed-effects model was used. Meta-analysis showed that using dexmedetomidine for sedation reduced the total hospital stay of children with ARF compared with propofol 


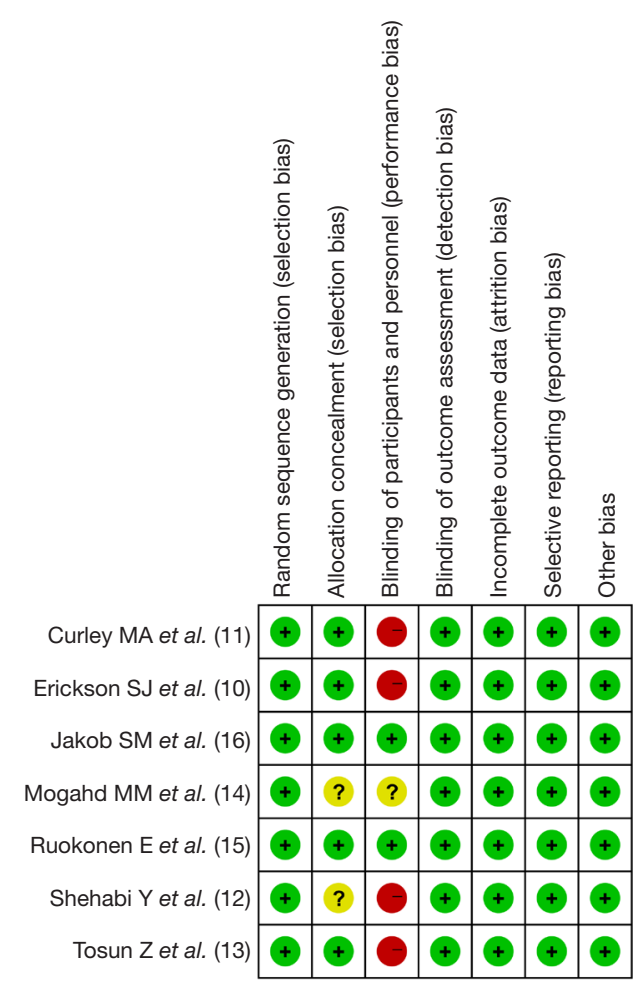

Figure 2 Summary of literature bias (10-16).
$[\mathrm{MD}=-1.94 ; 95 \% \mathrm{CI}:(-2.63,-1.25) ; \mathrm{Z}=5.48 ; \mathrm{P}<0.00001]$, as shown in Figure 6.

\section{Mortality}

A total of 3 studies (10-12) reported deaths after the intervention of the two sedatives. There was no statistical heterogeneity $\left(\mathrm{I}^{2}=0 \% ; \mathrm{P}=0.79\right)$. The fixed-effects model was used. Meta-analysis results showed that the effect of dexmedetomidine sedation compared with propofol on mortality was not statistically significant $[\mathrm{OR}=0.48 ; 95 \%$ CI: $(0.19,1.25) ; Z=1.50 ; P=0.13]$, as shown in Figure 7.

\section{Adverse reactions}

A total of 3 studies $(10,13,15)$ reported the incidence rate of adverse reactions (bradycardia and hypotension) after the intervention of the two sedatives.

There was no statistical heterogeneity among the literature for bradycardia $\left(\mathrm{I}^{2}=0 \% ; \mathrm{P}=0.74\right)$. The fixedeffects model was used. Meta-analysis results showed that the incidence rate of bradycardia with dexmedetomidine sedation was higher than with propofol [OR $=12.30 ; 95 \%$ CI: $(2.28,66.47) ; \mathrm{Z}=2.92 ; \mathrm{P}=0.004]$, as shown in Figure 8.

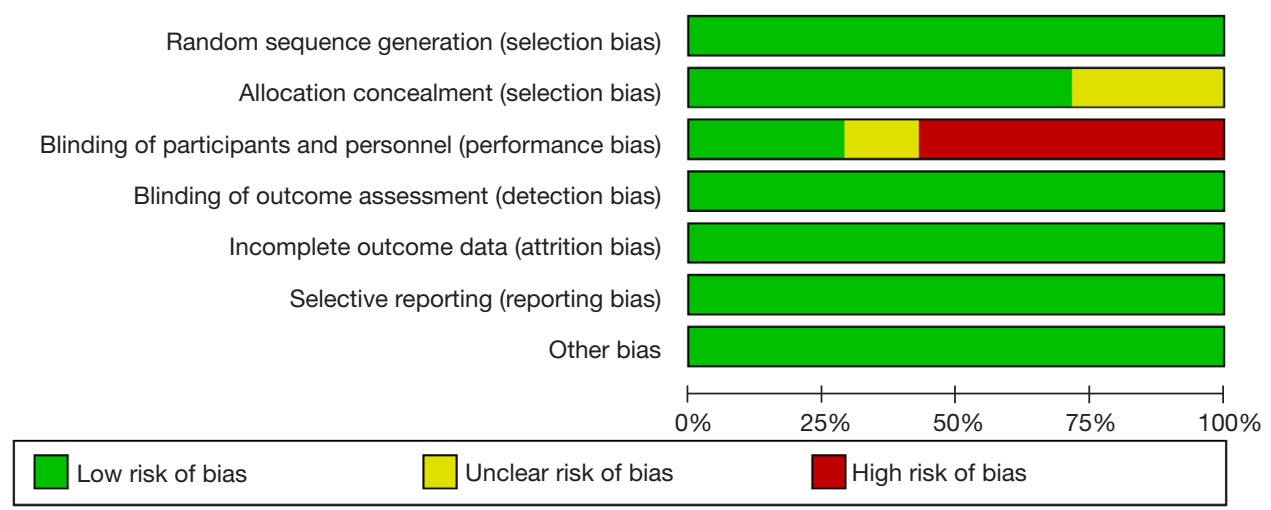

Figure 3 Literature bias plot.

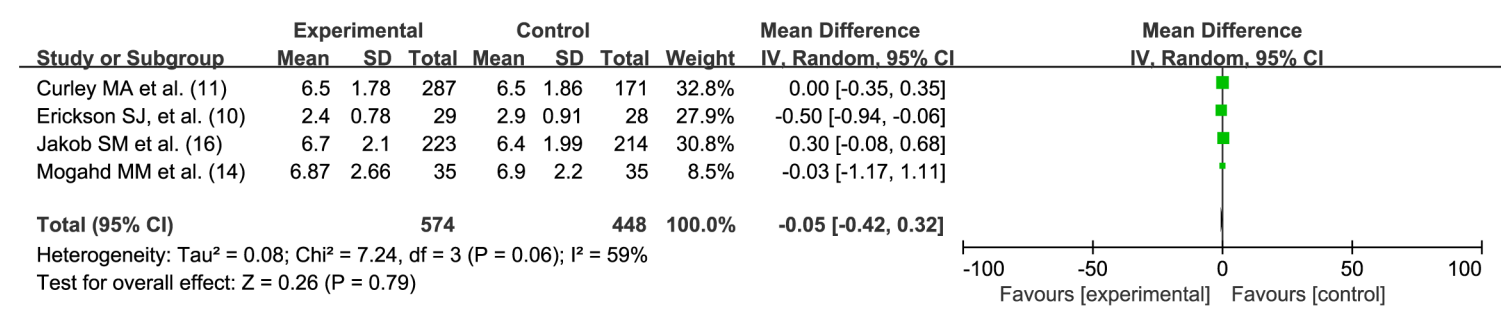

Figure 4 Comparison of the effects of dexmedetomidine and propofol sedative on tracheal intubation time in children with ARF $(10,11,14,16)$. ARF, acute respiratory failure; CI, confidence interval; SD, standard deviation. 


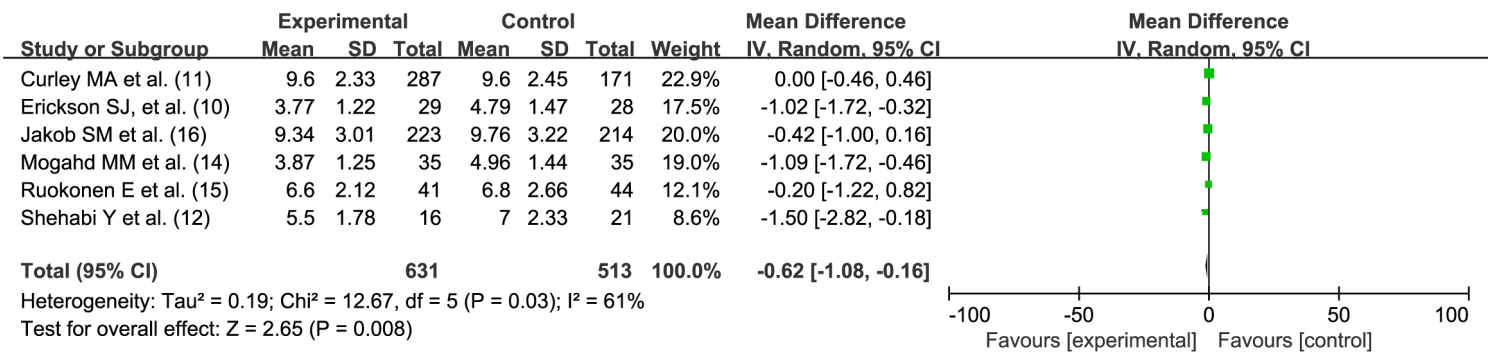

Figure 5 Comparison of the effect of dexmedetomidine and propofol sedative on ICU length of stay in children with ARF (10-12,14-16). ARF, acute respiratory failure; CI, confidence interval; SD, standard deviation.

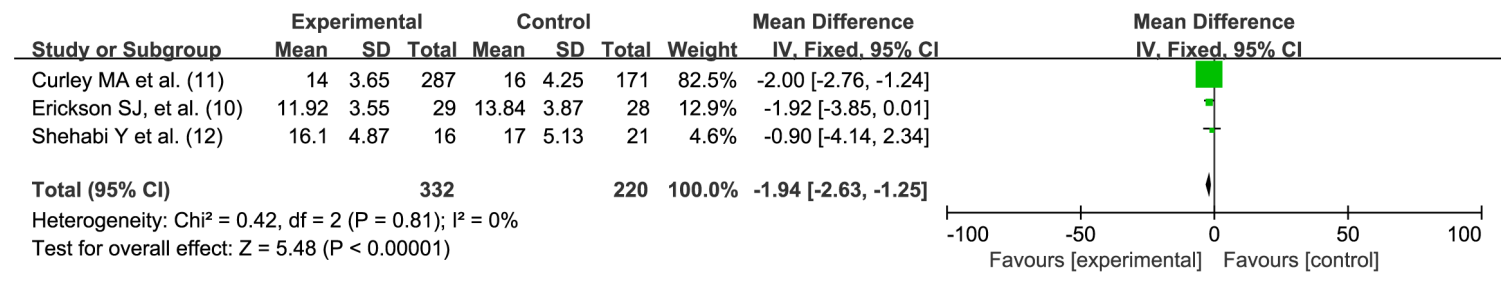

Figure 6 Comparison of the effect of dexmedetomidine and propofol sedative on length of hospital stay in children with ARF (10-12). ARF, acute respiratory failure; CI, confidence interval; SD, standard deviation.

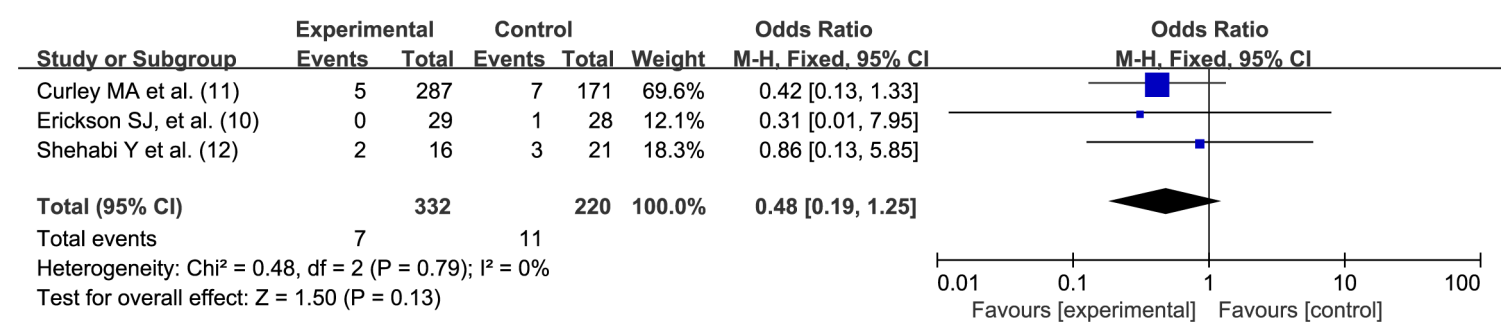

Figure 7 Comparison of the effect of dexmedetomidine and propofol sedative on mortality in children with ARF (10-12). ARF, acute respiratory failure; CI, confidence interval.

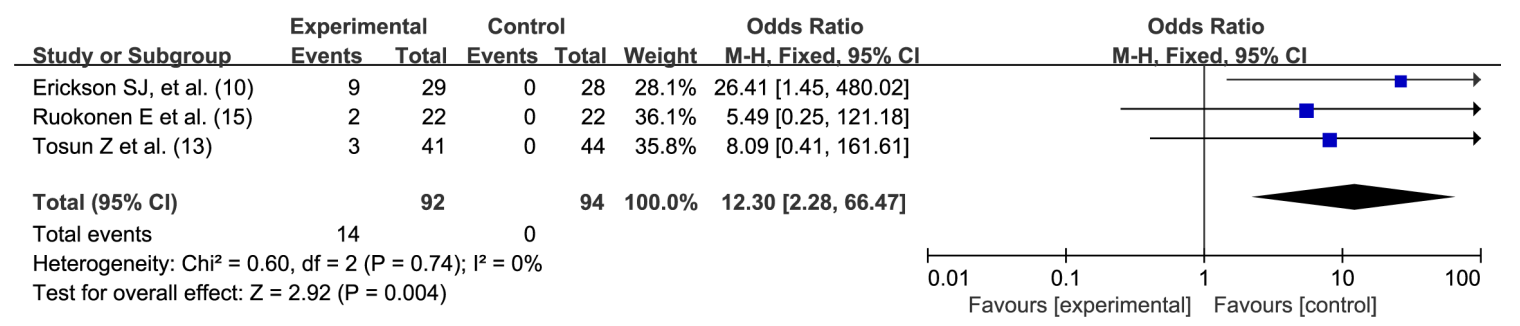

Figure 8 Comparison of incidence rate of bradycardia after dexmedetomidine and propofol sedation in children with ARF (10,13,15). ARF, acute respiratory failure; CI, confidence interval. 


\begin{tabular}{|c|c|c|c|c|c|c|c|c|c|c|c|}
\hline Study or Subaroup & $\begin{array}{l}\text { Experim } \\
\text { Events }\end{array}$ & $\begin{array}{l}\text { Total } \\
\text { Total }\end{array}$ & $\begin{array}{l}\text { Contr } \\
\text { Events }\end{array}$ & $\begin{array}{l}\text { ol } \\
\text { Total }\end{array}$ & Weight & $\begin{array}{c}\text { Odds Ratio } \\
\text { M-H. Fixed. 95\% Cl }\end{array}$ & & & $\begin{array}{c}\text { Odds Ratio } \\
\text { M-H. Fixed. } 95 \% \mathrm{Cl}\end{array}$ & & \\
\hline Erickson SJ, et al. (10) & 5 & 29 & 0 & 28 & $31.1 \%$ & $12.80[0.67,243.26]$ & & & & - & \\
\hline Ruokonen E et al. (15) & 2 & 41 & 0 & 44 & $34.0 \%$ & $5.63[0.26,120.91]$ & & & & & \\
\hline Tosun $Z$ et al. (13) & 1 & 22 & 0 & 22 & $35.0 \%$ & $3.14[0.12,81.35]$ & & & & & \\
\hline Total $(95 \% \mathrm{Cl})$ & & 92 & & 94 & $100.0 \%$ & $6.99[1.22,39.86]$ & & & & & \\
\hline Total events & 8 & & 0 & & & & & & & & \\
\hline \multicolumn{7}{|c|}{ Heterogeneity: $\mathrm{Chi}^{2}=0.41, \mathrm{df}=2(\mathrm{P}=0.81) ; \mathrm{I}^{2}=0 \%$} & 0.01 & 0.1 & 1 & 10 & 100 \\
\hline
\end{tabular}

Figure 9 Comparison of incidence rate of hypotension after dexmedetomidine and propofol sedation in children with ARF (10,13,15). ARF, acute respiratory failure; CI, confidence interval.

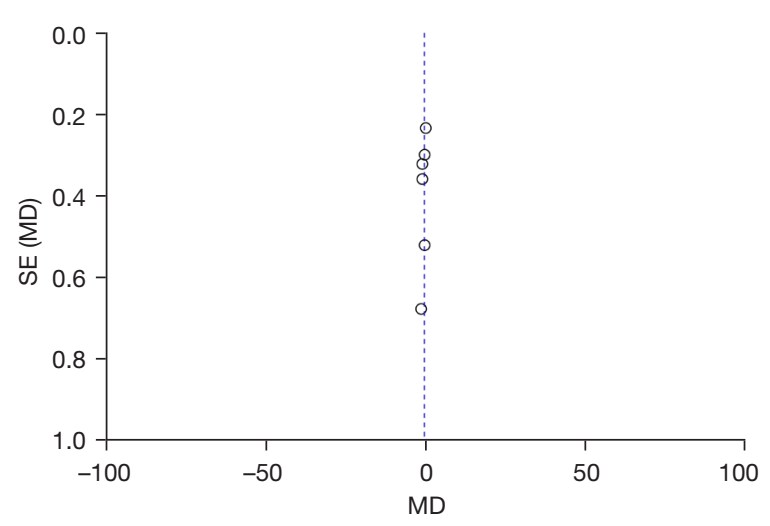

Figure 10 Funnel plot for indicators of ICU length of stay. ICU, intensive care unit; $\mathrm{SE}$, standard error; $\mathrm{MD}$, mean difference.

There was no statistical heterogeneity among the literature for hypotension $\left(\mathrm{I}^{2}=0 \% ; \mathrm{P}=0.81\right)$. The fixedeffects model was used. Meta-analysis results showed that the incidence rate of hypotension with dexmedetomidine sedation was higher than that with propofol $[\mathrm{OR}=6.99 ; 95 \%$ CI: (1.22, 39.86); $\mathrm{Z}=2.19 ; \mathrm{P}=0.03$ ], as shown in Figure 9.

\section{Source of heterogeneity and sensitivity analysis}

In the analysis of indicators of ICU length of stay, there was statistical heterogeneity among the studies $\left(\mathrm{I}^{2}=61 \%\right.$; $\mathrm{P}=0.03)$. The generation of heterogeneity can be related to the age and primary disease of the children. However, most of the included studies did not specify the mean age and primary disease type of the children, so we could not perform a subgroup analysis. However, there was little difference in the results between the random-effects model and the fixed-effects model, showing that the results had good stability (good sensitivity).

\section{Analysis of publication bias}

In the analysis of ICU admission time indicators, the funnel plot (Figure 10) was essentially evenly distributed, suggesting that the publication bias was small.

\section{Discussion}

Using dexmedetomidine as the sedative could reduce the length of stay in the PICU and reduce the total length of hospital stay for children with ARF compared with propofol, but there was no statistically significant difference in the effects on MV time or mortality. Studies have shown that dexmedetomidine can significantly reduce the occurrence of delirium in elderly patients compared with propofol $(17,18)$, but because no study reported this index in our study, it is impossible to determine the effect of dexmedetomidine on the occurrence of postoperative delirium in children.

Dexmedetomidine, as a highly selective $\alpha 2$-adrenergic receptor agonist, has a much greater affinity for $\alpha 2$ receptors than $\alpha 1$, and in addition to its sedative effect, also exerts analgesic effects by binding to $\alpha 2$ receptors in the spinal cord, thereby reducing the dose of opioids (19). Propofol is a short-acting anesthetic and commonly used in induction and maintenance of anesthesia in adults. When used as a sedative drug for patients undergoing artificial ventilation under intensive monitoring, the infusion rate should be adjusted according to the required depth of sedation. Generally, within $0.3-0.4 \mathrm{mg} / \mathrm{kg} / \mathrm{h}$ should obtain a satisfactory sedative effect (20). Zhang et al. found that dexmedetomidine was superior to propofol in reducing ICU length of stay and reducing the risk of delirium for sedation in ICU patients, but adverse effects occurred when dexmedetomidine was administered at a loading dose or at a high infusion rate (21).

Adverse effects of dexmedetomidine are primarily cardiovascular, and it can cause bradycardia and hypotension by acting on the $\alpha 2$ receptors of the heart (22). In this study, dexmedetomidine was used as a sedative in children with 
$\mathrm{ARF}$, and the incidence rates of bradycardia and hypotension were higher than with propofol. Therefore, special attention should be paid to the safety of dexmedetomidine in critically ill pediatric patients, and if bradycardia or hypotension occurs, the infusion of dexmedetomidine should be reduced or discontinued immediately, fluid replacement should be increased, or vasoactive drugs should be administered (23).

Dexmedetomidine is widely used in clinical pediatric medicine, such as cardiac catheterization (24), magnetic resonance imaging (25), airway foreign body removal (26), and the application of dexmedetomidine sedation can reduce pain in children and improve their compliance. Piastra et al. stated in a case series that early use of dexmedetomidine in infants/children receiving a ventilator for ARF can be considered safe, with the ability to improve recruitment and support ventilator synchrony in patients (27).

The use of dexmedetomidine for sedation in pediatric patients requires special attention to dosage; Erkonen et al. reported a 2-year-old child with traumatic brain injury who developed hypertension several hours after dexmedetomidine infusion at $4 \mathrm{mg} / \mathrm{kg} / \mathrm{h}$ (28). In the study by Sayed et al. (29), the investigators divided MV infants/children into highdose and low-dose groups according to the dosage of dexmedetomidine. The low-dose group was given a dosage of $0.25 \mu \mathrm{g} / \mathrm{kg}$ for $10 \mathrm{~min}$, followed by a maintenance dose rate of $0.25 \mu \mathrm{g} / \mathrm{kg} / \mathrm{h}$ for $50 \mathrm{~min}$, while the high-dose group was given a dosage of $0.5 \mu \mathrm{g} / \mathrm{kg}$ for $10 \mathrm{~min}$, followed by a maintenance dose rate of $0.5 \mu \mathrm{g} / \mathrm{kg} / \mathrm{h}$ for $50 \mathrm{~min}$. Their results showed that the high-dose group had better depth of sedation, and shorter ICU and hospital stays, which suggested that a dose rate of $0.5 \mu \mathrm{g} / \mathrm{kg} / \mathrm{h}$ was safe.

It has been suggested that dexmedetomidine is a better option from an economic point of view than standard sedatives when providing mild to moderate ICU sedation for more than $24 \mathrm{~h}$ (30), and the potential reason for its savings is mainly a reduction in extubation time.

In this study, the heterogeneity among the literature came from multiple aspects such as the age and disease characteristics of the children. The funnel plot suggested that the publication bias was small. Some of the studies included in this meta-analysis did not perform a blind method (10-13), the number of included studies was small, and the sample sizes were on average small.

\section{Conclusions}

A total of 1,188 patients in 7 studies were included in this meta-analysis. The results showed that the application of dexmedetomidine as the main sedative in the treatment of children with ARF could significantly reduce the PICU and hospital stays compared with propofol, but bradycardia and hypotension may occur during treatment, which requires close attention and timely intervention. However, due to the small number of included studies, this topic still needs to be deeply explored in a RCT.

\section{Acknowledgments}

Funding: None.

\section{Footnote}

Reporting Checklist: The authors have completed the PRISMA reporting checklist. Available at https:// tp.amegroups.com/article/view/10.21037/tp-22-20/rc

Conflicts of Interest: All authors have completed the ICMJE uniform disclosure form (available at https://tp.amegroups. com/article/view/10.21037/tp-22-20/coif). The authors have no conflicts of interest to declare.

Ethical Statement: The authors are accountable for all aspects of the work in ensuring that questions related to the accuracy or integrity of any part of the work are appropriately investigated and resolved.

Open Access Statement: This is an Open Access article distributed in accordance with the Creative Commons Attribution-NonCommercial-NoDerivs 4.0 International License (CC BY-NC-ND 4.0), which permits the noncommercial replication and distribution of the article with the strict proviso that no changes or edits are made and the original work is properly cited (including links to both the formal publication through the relevant DOI and the license). See: https://creativecommons.org/licenses/by-nc-nd/4.0/.

\section{References}

1. Gonzales JP, Child D, Harrington T, et al. Assessment and Impact of Intravenous Medication Fluid Administration in Critically Ill Patients With Acute Respiratory Failure. Ann Pharmacother 2022;56:35-43.

2. Kim LH, Duncan J, Yang CL. Juvenile Dermatomyositis and Acute Respiratory Failure in a Teen. Chest 2021;160:e619-22.

3. Brooks R, Cohen-Cymberknoh M, Glicksman C, et al. 
Manual external chest compression reverses respiratory failure in children with severe air trapping. Pediatr Pulmonol 2021;56:3887-90.

4. Grant MJ, Schneider JB, Asaro LA, et al. Dexmedetomidine Use in Critically Ill Children With Acute Respiratory Failure. Pediatr Crit Care Med 2016;17:1131-41.

5. Vet NJ, Kleiber N, Ista E, et al. Sedation in Critically Ill Children with Respiratory Failure. Front Pediatr 2016;4:89.

6. Sperotto F, Mondardini MC, Vitale F, et al. Prolonged sedation in critically ill children: is dexmedetomidine a safe option for younger age? An off-label experience. Minerva Anestesiol 2019;85:164-72.

7. Zhang Z, Chen K, Ni H, et al. Sedation of mechanically ventilated adults in intensive care unit: a network metaanalysis. Sci Rep 2017;7:44979.

8. Kim JY, Kim KN, Kim DW, et al. Effects of dexmedetomidine sedation for magnetic resonance imaging in children: a systematic review and meta-analysis. J Anesth 2021;35:525-35.

9. Dong Q, Li C, Xiao F, et al. Efficacy and safety of dexmedetomidine in patients receiving mechanical ventilation: Evidence from randomized controlled trials. Pharmacol Res Perspect 2020;8:e00658.

10. Erickson SJ, Millar J, Anderson BJ, et al. Dexmedetomidine Sedation in Mechanically Ventilated Critically Ill Children: A Pilot Randomized Controlled Trial. Pediatr Crit Care Med 2020;21:e731-9.

11. Curley MA, Wypij D, Watson RS, et al. Protocolized sedation vs usual care in pediatric patients mechanically ventilated for acute respiratory failure: a randomized clinical trial. JAMA 2015;313:379-89.

12. Shehabi Y, Bellomo R, Reade MC, et al. Early goaldirected sedation versus standard sedation in mechanically ventilated critically ill patients: a pilot study. Crit Care Med 2013;41:1983-91.

13. Tosun Z, Akin A, Guler G, et al. Dexmedetomidineketamine and propofol-ketamine combinations for anesthesia in spontaneously breathing pediatric patients undergoing cardiac catheterization. J Cardiothorac Vasc Anesth 2006;20:515-9.

14. Mogahd MM, Mahran MS, Elbaradi GF. Safety and efficacy of ketamine-dexmedetomidine versus ketaminepropofol combinations for sedation in patients after coronary artery bypass graft surgery. Ann Card Anaesth 2017;20:182-7.

15. Ruokonen E, Parviainen I, Jakob SM, et al.
Dexmedetomidine versus propofol/midazolam for longterm sedation during mechanical ventilation. Intensive Care Med 2009;35:282-90.

16. Jakob SM, Ruokonen E, Grounds RM, et al. Dexmedetomidine vs midazolam or propofol for sedation during prolonged mechanical ventilation: two randomized controlled trials. JAMA 2012;307:1151-60.

17. Pereira JV, Sanjanwala RM, Mohammed MK, et al. Dexmedetomidine versus propofol sedation in reducing delirium among older adults in the ICU: A systematic review and meta-analysis. Eur J Anaesthesiol 2020;37:121-31.

18. Liu X, Xie G, Zhang K, et al. Dexmedetomidine vs propofol sedation reduces delirium in patients after cardiac surgery: A meta-analysis with trial sequential analysis of randomized controlled trials. J Crit Care 2017;38:190-6.

19. Tsaousi GG, Lamperti M, Bilotta F. Role of Dexmedetomidine for Sedation in Neurocritical Care Patients: A Qualitative Systematic Review and Metaanalysis of Current Evidence. Clin Neuropharmacol 2016;39:144-51.

20. Abowali HA, Paganini M, Enten G, et al. Critical Review and Meta-Analysis of Postoperative Sedation after Adult Cardiac Surgery: Dexmedetomidine Versus Propofol. J Cardiothorac Vasc Anesth 2021;35:1134-42.

21. Zhang H, Fang B, Zhou W. The efficacy of dexmedetomidine-remifentanil versus dexmedetomidinepropofol in children undergoing flexible bronchoscopy: A retrospective trial. Medicine (Baltimore) 2017;96:e5815.

22. Castillo RL, Ibacache M, Cortínez I, et al. Dexmedetomidine Improves Cardiovascular and Ventilatory Outcomes in Critically Ill Patients: Basic and Clinical Approaches. Front Pharmacol 2020;10:1641.

23. Chen K, Lu Z, Xin YC, et al. Alpha-2 agonists for longterm sedation during mechanical ventilation in critically ill patients. Cochrane Database Syst Rev 2015;1:CD010269.

24. Joshi VS, Kollu SS, Sharma RM. Comparison of dexmedetomidine and ketamine versus propofol and ketamine for procedural sedation in children undergoing minor cardiac procedures in cardiac catheterization laboratory. Ann Card Anaesth 2017;20:422-6.

25. Heard C, Burrows F, Johnson K, et al. A comparison of dexmedetomidine-midazolam with propofol for maintenance of anesthesia in children undergoing magnetic resonance imaging. Anesth Analg 2008;107:1832-9.

26. Chen K, Shen X. Dexmedetomidine and propofol total intravenous anesthesia for airway foreign body removal. Ir J Med Sci 2014;183:481-4. 
27. Piastra M, Pizza A, Gaddi S, et al. Dexmedetomidine is effective and safe during NIV in infants and young children with acute respiratory failure. BMC Pediatr 2018;18:282.

28. Erkonen G, Lamb F, Tobias JD. High-dose dexmedetomidine-induced hypertension in a child with traumatic brain injury. Neurocrit Care 2008;9:366-9.

29. Sayed JA, Riad MAF, Abdel-Ghaffar HS. Effects of two dosing cohorts of dexmedetomidine as a primary sedative

Cite this article as: Xiao Z, He T, Jiang X, Xie F, Xia L, Zhou H. Effect of dexmedetomidine and propofol sedation on the prognosis of children with severe respiratory failure: a systematic review and meta-analysis. Transl Pediatr 2022;11(2):260-269. doi: 10.21037/tp-22-20 in critically ill infants with respiratory failure. Alexandria Journal of Pediatrics 2019;32:107.

30. Turunen H, Jakob SM, Ruokonen E, et al. Dexmedetomidine versus standard care sedation with propofol or midazolam in intensive care: an economic evaluation. Crit Care 2015;19:67.

(English Language Editor: K. Brown) 